\title{
Application of FTA $®$ Cards for detection and storage of avian influenza virus
}

\author{
Michał Jóźwiak, Krzysztof Wyrostek, \\ Katarzyna Domańska-Blicharz, Monika Olszewska-Tomczyk, \\ Krzysztof Śmietanka, Zenon Minta \\ Department of Poultry Diseases, \\ National Veterinary Research Institute, 24-100 Pulawy, Poland \\ michal.jozwiak@piwet.pulawy.pl
}

Received: November 10, 2015 Accepted: March 10, 2016

\begin{abstract}
Introduction: The aim of the study was to test the utility of Flinders Technology Associates filter paper (FTA® Cards) for molecular detection and storage of avian influenza virus (AIV). Material and Methods: There were two strains of AIV used in the study: low pathogenicity H7N1 and high pathogenicity H5N1 subtypes. Detection of viral material was conducted using molecular RT-PCR and rRT- PCR method. Results: The infectivity of LPAIV/H7N1 and HPAIV/H5N1 was completely inactivated within $1 \mathrm{~h}$ and $24 \mathrm{~h}$ after adsorption to FTA ${ }^{\circledR}$ Cards at room temperature, respectively. Viruses stored on FTA ${ }^{\circledR}$ Cards had detection limit approximately $1 \log _{10}$ lower than live viruses. Viral RNA of both strains were detectable on the cards by rRT-PCR for a minimum of $150 \mathrm{~d}$, irrespectively of storage temperatures (room temperature, $-20^{\circ} \mathrm{C}$ ). RNA was also detected in all samples obtained from SPF chickens experimentally infected with HPAI/H5N1 on $3^{\text {rd }}$ and $4^{\text {th }}$ day post-infection (p.i.). Conclusion: FTA ${ }^{\circledR}$ Cards enable safe and effective alternative transport of samples for molecular diagnosis of AIV.
\end{abstract}

Keywords: avian influenza virus, FTA® Cards, molecular detection, storage.

\section{Introduction}

Shipment of samples, particularly the hazardous biological materials posing potential risk of infection to animals and humans, requires biosafety and specific time-temperature conditions. The special conditions during transport are essential in order to assure safety of laboratory personnel handling samples and successful accomplishment of diagnostic process. Presently, there is a need for development of ways which would allow for simple and safe transport of hazardous biological materials, their testing, and implementation for routine use. Application of FTA ${ }^{\circledR}$ Cards is an example of such a safe method of handling and shipment the materials (6).

Avian influenza (AI) is one of the most dangerous infectious avian diseases. Its outbreaks are regularly reported and laboratory-confirmed cases have imposed the implementation of the strict eradication programme (2). Monitoring programmes are used for the detection of circulating AI viruses (AIV), especially H5 and H7 subtypes which present a risk for poultry health, but some of them can be also dangerous for humans. Many human infections caused by the $\mathrm{H} 5 \mathrm{~N} 1$, a highly pathogenic (HP) AIV, as well as other AI virus strains with zoonotic potential, e.g. $\mathrm{H} 7 \mathrm{~N} 7$ and $\mathrm{H} 5 \mathrm{~N} 8$, were laboratory-confirmed. These reasons indicate the need for alternative method of safe and reliable collection and transport of AIV strains as well as their analysis and validation $(4,12)$.

The Flinders Technology Associates filter paper (FTA ${ }$ Cards) is a special kind of filter paper containing chemicals which denaturise proteins of microbials, lyse the cells, and bind the released nucleic acids protecting them against UV radiation and oxidation. A complete and fast inactivation of infectious material plays a key role in safe transport and also during preparation and analysis of the samples. The use of FTA ${ }^{\circledR}$ Cards does not require cold chain conditions during the transport as the producer guarantees that the material collected on them is stable during the storage in laboratory conditions. In the last few years, many analyses were conducted, which revealed the usefulness of FTA ${ }^{\circledR}$ Cards for sampling, 
inactivation, and storage of viruses such as Marek's disease virus, infectious bronchitis virus, or infectious bursal disease virus $(3,7,8)$. Less is known about the effectiveness of FTA ${ }^{\circledR}$ Cards in relation to avian Ortho- and Paramyxoviridae such as AIV (1). There was only one study on AIV in which the inactivation of the virus, sensitivity of detection, and stability of cards coated with LPAIV H6N2 and HPAIV H5N1 were established (1). However, there is a need to evaluate more of the different AIV strains on FTA ${ }^{\circledR}$ Cards, especially $\mathrm{H} 5$ and $\mathrm{H} 7$ types, mainly because of their zoonotic potential. Other studies analysed the stability of viruses on FTA ${ }^{\circledR}$ Cards at temperatures higher than the room temperature. For example, infectious bronchitis virus remained detectable up to $15 \mathrm{~d}$ at $41^{\circ} \mathrm{C}$; but there is no data whether AI viruses would be detectable at this temperature $(1,3,7,8)$.

The aim of this study was to evaluate the utility of FTA ${ }^{\circledR}$ Cards for safe transport of AIV samples and to define the stability of the viral material (allantoic fluids, swabs, and tissues imprints containing the viruses) stored at different temperatures.

\section{Material and Methods}

Viruses. The following avian influenza viruses were used in the study: low pathogenic reference strain H7 subtype: LPAIV/H7N1 A/African starling/England/ 983/79 (source: AHVLA Weybridge) and high pathogenic strain H5 subtype: HPAIV/H5N1 A/turkey/ Poland/35/07 (from the collection of the Department of Poultry Diseases, National Veterinary Research Institute, Pulawy, Poland).

The AIV strains were propagated for 9-10 d on specific pathogen free (SPF) chicken embryos infected into the allantoic cavity. Allantoic fluids (AF) collected from dead or cooled embryos on 5-6 d post-infection (p.i.) were tested for the haemagglutination activity (HA) and after pooling the EID $_{50}$ titre was measured. From the titres obtained at $10^{7.5} \mathrm{EID}_{50} / \mathrm{mL}$ for LPAIV/H7N1 and $10^{9.3} \mathrm{EID}_{50} / \mathrm{mL}$ for $\mathrm{HPAIV} / \mathrm{H} 5 \mathrm{~N} 1$, the initial dilutions at $10^{6} \mathrm{EID}_{50} / \mathrm{mL}$ were prepared. The viral materials were stored at $-70^{\circ} \mathrm{C}$ before use. Allantoic fluids collected from uninfected SPF chicken embryos were used as negative control.

FTA ${ }^{\circledR}$ Cards. Two kinds of FTA $^{\circledR}$ Cards were used in the tests: FTA $^{\circledR}$ Classic Card assigned for tissues imprints, blood, and oropharyngeal and cloacal swabs and Indicating FTA ${ }^{\circledR}$ Classic Card, with the colour indicator assigned for allantoic fluids.

RNA extraction. In order to extract the viral RNA, the commercial RNeasy Mini Kit (Qiagen, Germany) was applied. The extraction was conducted according to the manufacturer's instruction.

RT-PCR reactions. $R T-P C R$ in real time (real time RT-PCR, rRT-PCR) for detection of matrix protein gene (rRT-PCR/M) of influenza A viruses was performed using primers and probes designed by
Spackman (15). Conventional RT-PCR for detection of AIV H5 subtype (RT-PCR/H5) and AIV H7 subtype (RT-PCR/H7) were conducted using primers designed by Starick (16).

Sequencing. Reaction products of RT-PCR/H5 and RT-PCR/H7 were sequenced using sequencer 3500 Series Genetic Analyser (Applied Biosystems, USA) according to the standard procedure.

Inactivation of AI viruses on FTA ${ }^{\circledR}$ Cards. The strains of AIV at a concentration of $10^{6} \mathrm{EID}_{50} / \mathrm{mL}$ were spotted onto FTA $^{\circledR}$ Classic Card area with a colour indicator in amount of $0.1 \mathrm{~mL}$ in the middle of the sample area (four round areas on card) and was stored at room temperature $\left(21^{\circ} \mathrm{C} \pm 3\right)$ in a plastic bag. The analyses were conducted in two repeats for three durations: $1 \mathrm{~h}, 1 \mathrm{~d}$, and $3 \mathrm{~d}$ after spotting onto cards. Whole sample areas with the viral material were cut out, then placed in $1 \mathrm{~mL}$ of phosphate buffered saline (PBS, pH 7.2), and centrifuged (1500 rpm, $10 \mathrm{~min}$ ). Next, four SPF embryos were infected into allantoic sac on days 9-10 of incubation using prepared solution (0.2 $\mathrm{mL}$ per each embryo). Five-six days after the infection, the allantoic fluids were analysed on HA according to the standard diagnostic procedure. In the case of a negative result of HA, a blind passage on the embryos was performed.

Sensitivity of detection of the viral RNA from FTA ${ }^{\circledR}$ Cards. Ten-fold dilutions of allantoic fluids containing analysed AIV strains in TE buffer $(10 \mathrm{mM}$ of Tris- $\mathrm{HCl}, 0.1 \mathrm{mM}$ of EDTA, $\mathrm{pH} 8.0$ ) were prepared referring to doses from $10^{6} \mathrm{EID}_{50} / \mathrm{mL}$ to $10^{1} \mathrm{EID}_{50} / \mathrm{mL}$. Next, $0.1 \mathrm{~mL}$ of each dilution was instilled onto sample area of FTA ${ }^{\circledR}$ Classic Card with a colour indicator (two areas per each dilution) and the cards were left to dry at room temperature for at least $1 \mathrm{~h}$. Similarly, the negative control was prepared by applying of $0.1 \mathrm{~mL}$ of allantoic fluid collected from uninfected SPF chicken embryos. Next, $25 \%$ of the surface from each sample area was cut out and placed in Eppendorf tube with $0.2 \mathrm{~mL}$ TE buffer, mixed by vortex for $15 \mathrm{~s}$, and incubated at room temperature for about $10 \mathrm{~min}$. Afterwards, $0.1 \mathrm{~mL}$ of fluid was taken to isolate the RNA. For comparison, RNA was also isolated directly from the viral material dilutions. Identification of the viruses was conducted using rRT-PCR/M and RT-PCR/H5 RT-PCR/H7.

Stability of AIV RNA on FTA ${ }^{\circledR}$ Cards. The set of FTA ${ }^{\circledR}$ Classic Cards inoculated with $10^{6} \mathrm{EID}_{50} / \mathrm{mL}$ were incubated at room temperature for $1 \mathrm{~h}$ and then packed into a plastic bag. One group of the cards was stored at room temperature whereas the second group was placed at $-20^{\circ} \mathrm{C}$. Virus RNA was isolated after $1 \mathrm{~h}$ of storage and then after 1, 7, 30, 60, 90, 120, and 150 d. For comparison, the RNA was also isolated in the same conditions from initial virus dilution, previously used for application to $\mathrm{FTA}^{\circledR}$ Cards at a dose of $10^{6} \mathrm{EID}_{50} / \mathrm{mL}$, and stored at $-70^{\circ} \mathrm{C}$.

Detection of AIV from imprints of swabs and organs on FTA ${ }^{\circledR}$ Cards. The following samples were 
taken from 5- to 10-week-old SPF chickens infected i.n. and i.o. with $10^{6} \mathrm{EID}_{50}$ of H5N1 HPAIV strain per bird: cloacal and oropharyngeal swabs, and fragments of the lungs, spleen, kidneys, and brain. The samples were pressed onto the FTA $^{\circledR}$ Classic Card. Next, the cards were carried under biosecurity conditions to the laboratory and remained at room temperature until the analysis (3 d after sampling).

\section{Results}

Virus inactivation on FTA ${ }^{\circledR}$ Cards. The LPAI $\mathrm{H} 7 \mathrm{~N} 1$ virus was completely inactivated just after $1 \mathrm{~h}$ of virus storage at room temperature on $\mathrm{FTA}^{\circledR}$ Cards, as the virus was not propagated in the embryos inoculated with the material recovered from them (negative haemagglutination result after two blind passages). On the other hand, H5N1 HPAIV material recovered from FTA ${ }^{\circledR}$ Cards incubated for $1 \mathrm{~h}$ at room temperature and propagated in SPF embryos indicated infectivity at the first repeat (positive haemagglutination result), but was completely inactivated in the second repeat. There were no infectious $\mathrm{H} 5 \mathrm{~N} 1$ and $\mathrm{H} 7 \mathrm{~N} 1$ viruses (negative haemagglutination result) in the fluids collected from the embryos inoculated with the material recovered from FTA ${ }^{\circledR}$ Cards incubated for $24 \mathrm{~h}$ and $3 \mathrm{~d}$ at room temperature. These results indicate that to ensure total inactivation of AIV on FTA $^{\circledR}$ Cards they should be incubated more than $1 \mathrm{~h}$ from the moment of application of the viral material.

Sensitivity of detection the viral RNA from FTA ${ }^{\circledR}$ Cards. RNA of the AI viruses was detected from FTA $^{\circledR}$ Cards by rRT-PCR method (M gene AIV) up to dilutions corresponding to doses of $10^{3} \mathrm{EID}_{50} / \mathrm{mL}$ for LPAIV/H7N1 and $10^{5} \mathrm{EID}_{50} / \mathrm{mL}$ for HPAIV/H5N1. The detection rate for RNA of both viruses in allantoic fluid dilutions without their inactivation on FTA $^{\circledR}$ Cards was 10 times higher (Table 1). The virus dose required for subtype identification (through the sequencing of the products in RT-PCR/H5 and RT-PCR/H7 reactions) in comparison to rRT-PCR results for $\mathrm{FTA}^{\circledR}$ Cards was equal for $\mathrm{HPAI} / \mathrm{H} 5 \mathrm{~N} 1$ and 10-times higher for LPAI/H7N1 (Fig. 1).

Stability of AIV RNA on FTA ${ }^{\circledR}$ Cards. Stability of the viral RNA on FTA $^{\circledR}$ Cards which were soaked in allantoic fluids containing $\mathrm{AI}$ viruses (H7N1 and H5N1) of the initial concentration of about $10^{6} \mathrm{EID}_{50} / \mathrm{mL}$ was examined with $\mathrm{rRT}-\mathrm{PCR} / \mathrm{M}$, RT-PCR/H5, and RT-PCR/H7. RNA of both strains examined with the rRT-PCR/M method was detectable (Ct value $\leq 35$ considered as positive) from FTA ${ }^{\circledR}$ Cards until the last day of the analysis (150 d) during storage at both temperatures, similarly to the RNA of initial viral material stored at $-70^{\circ} \mathrm{C}$, although a decrease in RNA quantity in the analysed period was generally observed only in samples collected from FTA ${ }^{\circledR}$ Cards stored at room temperature (Table 2). The results of RT-PCR were comparable for both strains stored on FTA $^{\circledR}$ Cards at $-20^{\circ} \mathrm{C}$ : RNA of AIVs was detected until the last day of analysis, whereas their stability at room temperature was lower and RNA of both AIVs was detected up to $90 \mathrm{~d}$ (Fig. 2).

AIV detection from swabs and tissues on FTA ${ }^{\circledR}$ Cards. Positive results of rRT-PCR/M reaction for AIV were obtained for all types of samples (cloacal and oropharyngeal swabs as well as from the lungs, spleen, kidneys, and brain) collected on $\mathrm{FTA}^{\circledR}$ Cards 3 and $4 \mathrm{~d}$ after infection of the chickens with the AIV/H5N1 virus. The obtained $\mathrm{Ct}$ values indicated high concentration of the viral material in all analysed samples (Table 3). In the same kind of samples taken from control chickens on FTA $^{\circledR}$ Cards and analysed as described above, no viral RNA was detected.

Table 1. Results of rRT-PCR targeting the Matrix gene of LPAIV/H7N1 and HPAIV/H5N1 viral material isolated from FTA ${ }^{\circledR}$ Cards and straight from the allantoic fluid

\begin{tabular}{|c|c|c|c|c|}
\hline \multirow{2}{*}{ Virus dilution $\left(\mathrm{EID}_{50} / \mathrm{mL}\right)$} & \multicolumn{2}{|c|}{ LPAI/ H7N1 } & \multicolumn{2}{|c|}{ HPAI/H5N1 } \\
\hline & FTA $^{\circledR}$ Cards & Allantoic fluid & FTA $^{\circledR}$ Cards & Allantoic fluid \\
\hline $10^{6}$ & $23.92 \pm 0.9$ & $19.14 \pm 0.4$ & $30.21 \pm 0.7$ & $26.0 \pm 0.5$ \\
\hline $10^{5}$ & $27.19 \pm 0.8$ & $22.69 \pm 0.5$ & $34.86 \pm 1.1$ & $30.42 \pm 0.4$ \\
\hline $10^{4}$ & $30.52 \pm 1.0$ & $25.82 \pm 0.2$ & No $\mathrm{Ct}$ & $33.79 \pm 1.6$ \\
\hline $10^{3}$ & $33.88 \pm 0.9$ & $29.46 \pm 0.6$ & No Ct & No Ct \\
\hline $10^{2}$ & $37.71 \pm 0.7$ & $33.90 \pm 1.3$ & $\mathrm{No} C t$ & No Ct \\
\hline $10^{1}$ & No Ct & $36.87 \pm 1.6$ & No Ct & No Ct \\
\hline
\end{tabular}

Ct value $\leq 35$ - positive results 


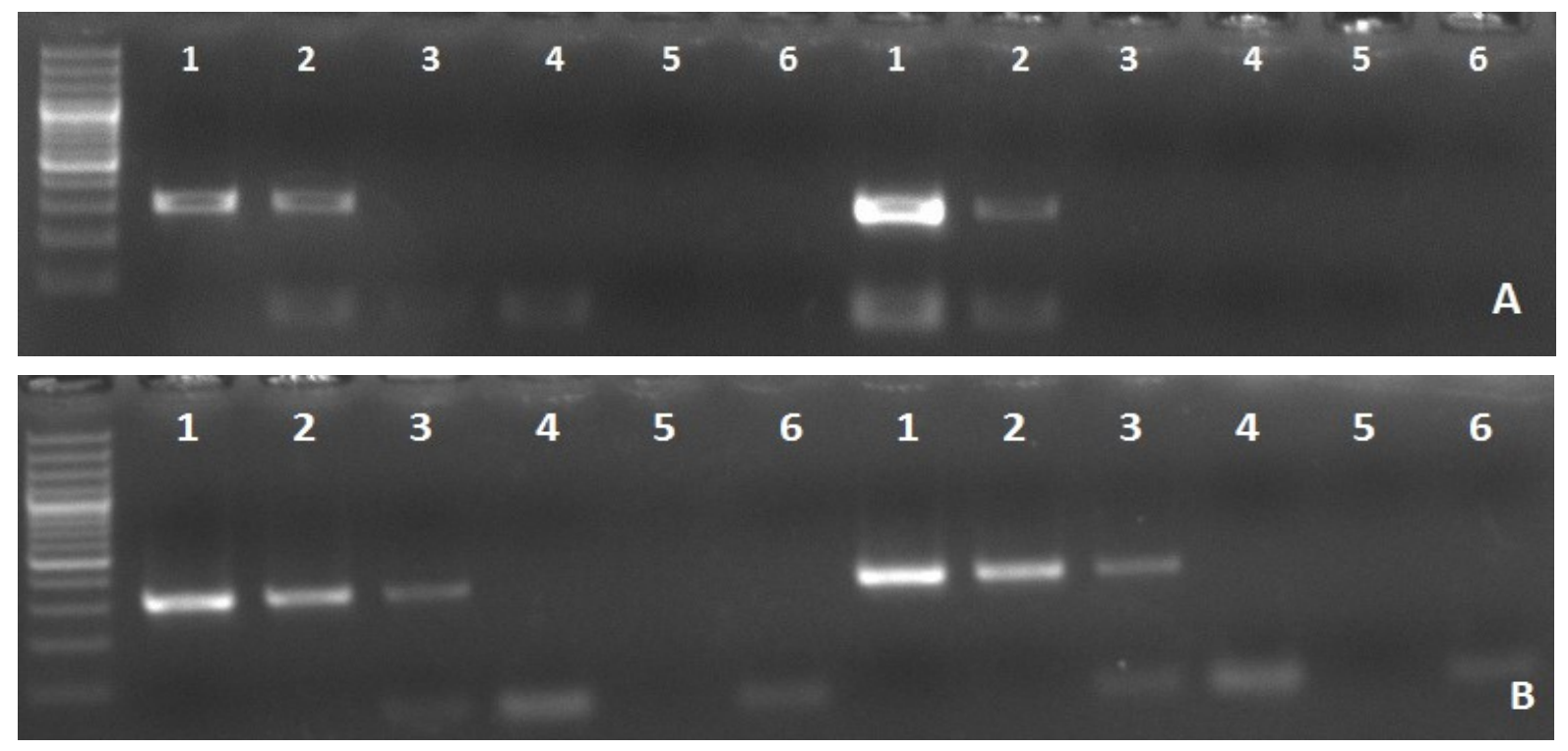

Fig. 1. Sensitivity of detection of the AIV/H5N1 from $\mathrm{FTA}^{\circledR}$ Cards (A) and from allantoic fluids (B). Lines 1 - 6: dilutions corresponding to doses $10^{6}, 10^{5}, 10^{4}, 10^{3}, 10^{2}$, and $10^{1} \mathrm{EID}_{50} / \mathrm{mL}$

Table 2. Mean $\mathrm{Ct}$ values obtained in rRT-PCR/M for LPAIV/H7N1 and HPAIV/H5N1 viruses isolated from FTA ${ }^{\circledR}$ Cards stored at different temperatures

\begin{tabular}{|c|c|c|c|c|c|c|c|c|c|}
\hline \multirow{3}{*}{ Virus } & \multirow{3}{*}{ Temp. } & \multicolumn{8}{|c|}{ Time after inoculation of FTA ${ }^{\circledR}$ Cards } \\
\hline & & $1 \mathrm{~h}$ & $1 \mathrm{~d}$ & $7 d$ & $30 \mathrm{~d}$ & $60 \mathrm{~d}$ & $90 \mathrm{~d}$ & $120 \mathrm{~d}$ & $150 \mathrm{~d}$ \\
\hline & & \multicolumn{8}{|c|}{$\mathrm{Ct}$ value } \\
\hline \multirow{6}{*}{ LPAIV } & \multirow{2}{*}{$20^{\circ} \mathrm{C}$} & 23.49 & 26.65 & 27.94 & 30.57 & 28.40 & 29.42 & 28.66 & 28.05 \\
\hline & & \pm 1.2 & \pm 1.9 & \pm 2.8 & \pm 0.1 & \pm 1.1 & \pm 0.5 & \pm 0.5 & \pm 1.1 \\
\hline & \multirow{2}{*}{$-20^{\circ} \mathrm{C}$} & \multirow{2}{*}{-} & 25.43 & 25.60 & 25.38 & 24.21 & 24.08 & 23.04 & 23.16 \\
\hline & & & \pm 2.1 & \pm 1.9 & \pm 0.4 & \pm 0.8 & \pm 0.3 & \pm 0.3 & \pm 0.4 \\
\hline & \multirow{2}{*}{$-70^{\circ} \mathrm{C}$} & 19.44 & 21.13 & 20.45 & 20.00 & 20.18 & 20.04 & 19.39 & 19.79 \\
\hline & & \pm 0.3 & \pm 2.4 & \pm 1.6 & \pm 0.2 & \pm 0.4 & \pm 0.70 & \pm 0.6 & \pm 0.5 \\
\hline \multirow{6}{*}{ HPAIV } & \multirow{2}{*}{$20^{\circ} \mathrm{C}$} & 27.99 & 27.79 & 28.22 & 33.09 & 32.48 & 31.53 & 31.52 & 31.56 \\
\hline & & \pm 1.9 & \pm 0.9 & \pm 0.8 & \pm 0.3 & \pm 0.6 & \pm 0.4 & \pm 0.1 & \pm 0.66 \\
\hline & \multirow{2}{*}{$-20^{\circ} \mathrm{C}$} & \multirow{2}{*}{-} & 27.74 & 27.19 & 30.49 & 29.23 & 27.29 & 27.12 & 26.42 \\
\hline & & & \pm 0.8 & \pm 0.3 & \pm 1.5 & \pm 0.5 & \pm 0.9 & \pm 0.65 & \pm 1.1 \\
\hline & \multirow{2}{*}{$-70^{\circ} \mathrm{C}$} & 23.23 & 22.50 & 23.99 & 27.93 & 25.74 & 24.77 & 23.38 & 22.84 \\
\hline & & \pm 1.5 & \pm 0.5 & \pm 0.2 & \pm 0.3 & \pm 0.1 & \pm 0.5 & \pm 0.2 & \pm 0.9 \\
\hline
\end{tabular}

Ct value $\leq 35$ - positive results

Table 3. Results of rRT-PCR targeting the M gene of the imprint samples collected on FTA® Classic Cards from five SPF chickens infected at the age of 10 weeks with HPAI/H5N1

\begin{tabular}{llc}
\hline \multirow{2}{*}{ Sample } & \multicolumn{2}{c}{ Days after infection } \\
\cline { 2 - 3 } & \multicolumn{2}{c}{4} \\
\hline Oropharyngeal swab & $18.03-22.82^{\mathrm{a}}$ & $17.83-19.80^{\mathrm{c}}$ \\
\hline Cloacal swab & $24,52-28.28^{\mathrm{a}}$ & $26.71-28.92^{\mathrm{c}}$ \\
\hline Lungs & $18.68-23.36^{\mathrm{b}}$ & $21.16-22.21^{\mathrm{c}}$ \\
\hline Spleen & $21.67-24.78^{\mathrm{b}}$ & $26.32-27.56^{\mathrm{c}}$ \\
\hline Kidneys & $19.54-22.57^{\mathrm{b}}$ & $20.59-22.48^{\mathrm{c}}$ \\
\hline Brain & $17.71-19.39^{\mathrm{b}}$ & $18.53-19.0^{\mathrm{c}}$ \\
\hline
\end{tabular}

a-Samples taken from all infected birds

b-Samples taken from three infected birds dead on $3 \mathrm{~d}$ p.i.

c-Samples taken from two infected birds dead on $4 \mathrm{~d}$ p.i. 

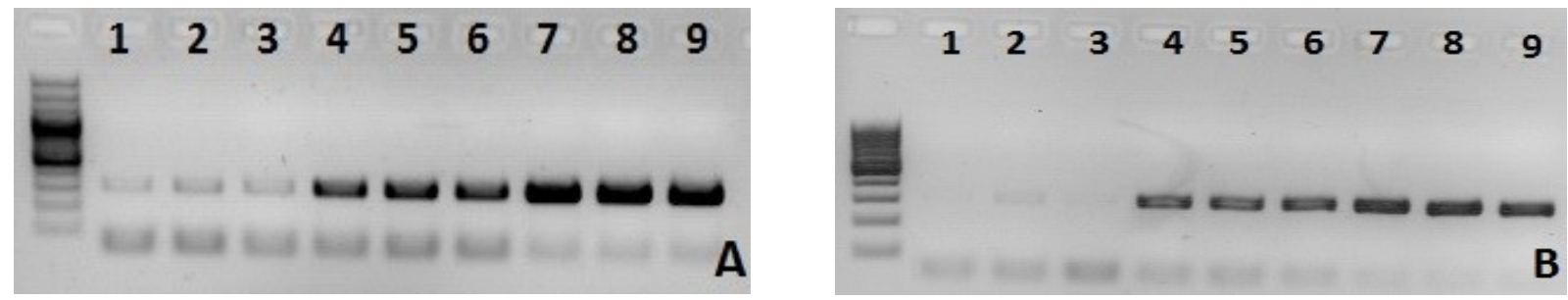

Fig. 2. Stability of AIV/H5N1 on $\mathrm{FTA}^{\circledR}$ Cards after $90 \mathrm{~d}(\mathrm{~A})$ and $120 \mathrm{~d}(\mathrm{~B})$ of storage at different temperatures. Lines: $1-3$ - at room temperature, $4-6$ - at $-20^{\circ} \mathrm{C}, 7-9-$ at $-70^{\circ} \mathrm{C}$

\section{Discussion}

The conducted tests demonstrated that the FTA ${ }^{\circledR}$ Cards can be useful for easy (shipment at room temperature condition) and safe (inactivated virus) transport of infective strains of avian influenza viruses. Nucleic acids of AIV spotted on FTA ${ }^{\circledR}$ Cards could be then used for diagnostic purposes, i.e. molecular detection and AIV subtype determination, and after molecular analysis also for pathogenicity identification $(1,11,14)$. Total inactivation of the AI viruses on FTA ${ }^{\circledR}$ Cards was achieved after $24 \mathrm{~h}$ of storage at room temperature. Lower quantity of virus detection from FTA ${ }^{\circledR}$ Cards in comparison to control allantoic fluid can be probably caused by sample volume taken for RNA isolation. About $25 \%$ of the card areas were punched from the FTA ${ }^{\circledR}$ Card, which is equal to $25 \mu \mathrm{L}$ of the total spotted volume $(100 \mu \mathrm{L})$, whereas the volume of the allantoic fluid taken for the direct isolation was $100 \mu \mathrm{L}$ (1). Limits of detection estimated for both AIV strains were different: $10^{3} \mathrm{EID}_{50} / \mathrm{mL}$ and $10^{5} \mathrm{EID}_{50} / \mathrm{mL}$ for LPAIV and HPAIV respectively. This observation is contrary to previous results which revealed no significant differences in the stability among the strains of the same viral species $(5,9,13)$. Although the viral RNA appears to be less stable than DNA during storage on FTA ${ }^{\circledR}$ Cards, it could be sufficiently preserved even for a long time (10). RNA of many AIV subtypes spotted on the FTA ${ }^{\circledR}$ Card could be detected by rRT-PCR up to $30 \mathrm{~d}$ at room temperature storage. Other H5N2, H7N3, and H9N2 AI viruses can be detectable up to $90 \mathrm{~d}$ p.i. and there are some isolates of H9N2 for which the possibility of detection reached up to $120 \mathrm{~d}$ p.i. at the same temperature (5). Viral RNA of the strains analysed in this study was detected from FTA ${ }^{\circledR}$ Cards up to at least $150 \mathrm{~d}$ storage at both temperatures using the rRT-PCR/M methods, and up to $90 \mathrm{~d}$ using the RT-PCR/H5 and RT-PCR/H7 methods for samples stored at room temperature. The storage of FTA ${ }^{\circledR}$ Cards inoculated with $\mathrm{AI}$ viruses at $-20^{\circ} \mathrm{C}$ promotes better stability of the detected RNA in comparison with the room temperature, where the possibility of detection and subtype identification was essentially lower for RT-PCR methods. By sequencing the target fragment (300 bp for $\mathrm{H} 5$ and $210 \mathrm{bp}$ for H7) and comparing it against the nucleotide database at the
NCBI website, we identified the analysed samples as AI Matrix gene fragment, and we could determine their pathogenicity. FTA ${ }^{\circledR}$ Cards were also assessed in respect of their use in the field for cloacal/ oropharyngeal swabs, as well as tissue imprints transport to laboratory for diagnostic purposes. We detected a large quantity of viral RNA isolated from FTA ${ }^{\circledR}$ Cards with swabs collected from experimentally infected chickens only on days 3 and 4 post infection, and oropharyngeal samples contained slightly higher AIV RNA amount than cloacal ones. The reason for this could be increased shedding of viral RNA via respiratory route rather than via the gastrointenstinal tract (5). Despite the results obtained in this experimental infection, another study of FTA ${ }^{\circledR}$ Cards inoculated with samples derived from wild birds naturally infected with different strains of LPAIV showed higher concentration of viral RNA in cloacal swabs (5). FTA ${ }^{\circledR}$ Cards may allow for the collection and preservation of undiluted virus-contaminated faecal material. Another reason is the difference between the specificity of infection and virus excretion in wild birds and poultry. Moreover, it has been shown that cloacal samples can be stored on FTA ${ }^{\circledR}$ Cards at room temperature for up to $30 \mathrm{~d}$ with limited risk of loss of the detection $(1,5)$. These observations indicate the need to control more than one type of the same virus, especially containing RNA, in order to define precisely the utility of the FTA ${ }^{\circledR}$ Cards for diagnostic tests before their routine application. The traditional sampling techniques for AIV field samples require special arrangements because of their hazardous nature. The most important is always storing the samples in ice bags or in liquid nitrogen during transport to the laboratory, and also maintaining cold chain conditions in further laboratory procedures prior to analysis. Our study also revealed that $1 \mathrm{~h}$ incubation of AIV on FTA ${ }^{\circledR}$ Cards is insufficient for total virus inactivation as tested viruses were still able to propagate on SPF eggs after this period. Our findings reconfirmed the usefulness of FTA ${ }^{\circledR}$ Cards for diagnostic purposes as they greatly limit the possibility of infection with dangerous virus strains during their transport, and concomitantly preserve viral RNA for laboratory testing. The study revealed that the use of FTA ${ }^{\circledR}$ Cards is an easy and effective alternative method for sampling and diagnosis of AI. However, it should be stressed that 
working with potentially infectious material always needs special care, as it can never be guaranteed that the infectious material has been completely inactivated.

Conflict of Interests Statement: The authors declare that they have no conflict of interests regarding the publication of this article.

Financial Disclosure Statement: This work was supported by S/096 Statutory Grant 'The use of FTA ${ }^{\circledR}$ Cards for the molecular diagnostic and epidemiology of avian influenza and Newcastle disease'.

Animal Rights Statement: None required.

Acknowledgements: The authors wish to thank Mrs Elżbieta Juszczuk for her excellent assistance.

\section{References}

1. Abdelwhab E.M., Luschow D., Harder T.C., Hafez H.M.: The use of $\mathrm{FTA}^{\circledR}$ filter papers for diagnosis of avian influenza virus. J Virol Methods 2011, 174, 120-122.

2. Act of 11 March 2004 on animal health protection and fighting against infectious animal diseases (Journal of Laws 2004, No. 69, item 625 with subsequent amendments).

3. Cortes A.L., Montiel E.R., Gimeno I.M.: Validation of Marek's disease diagnosis and monitoring of Marek's disease vaccines from samples collected in FTA $^{\circledR}$ Cards. Avian Dis 2009, 54, 510-516.

4. Kalthoff D., Globie A., Beer M.: (Highly pathogenic) avian influenza as a zoonotic agent. Vet Microbiol 2010, 140, (3-4), $237-245$.
5. Keeler S., Ferro P., Brown J., Jackwood M., Stallknecht D.: Use of FTA ${ }^{\circledR}$ Sampling Cards for molecular detection of avian influenza virus in wild birds. Avian Dis 2012, 56, 200-207.

6. Kraus R.H., van Hooft P., Waldenström J., Latorre-Margalef N., Ydenberg R.C., Prins H.H.: Avian influenza surveillance with FTA Cards. Field methods, biosafety, and transportation issues solved. J Visual Exp 2011, 54, 1-5.

7. Moscoso H., Alvarado I., Hofacre C.L.: Molecular analysis of infectious bursal disease virus from bursal tissues collected on FTA $^{\circledR}$ filter paper. Avian Dis 2006, 50, 391-396.

8. Moscoso H., Raybon E.O., Thayer S.G., Hofacre C.L.: Molecular detection and serotyping of infectious bronchitis virus from FTA ${ }^{\circledR}$ filter paper. Avian Dis 2005 49, 24-29.

9. Narayanan M.S., Parthiban M., Sathiya P., Kumanan K.: Molecular detection of Newcastle disease virus using Flinder Technology Associated-PCR. Vet Arch 2010, 80, 51-60.

10. Natarajan P., Trinh T., Mertz L., Goldsborough M., Fox D.K.: Paper-based archiving of mammalian and plant samples for RNA analysis. BioTechniques 2000, 29, 1328-1333.

11. OIE Manual of Diagnostic Tests and Vaccines for Terrestrial Animals (Mammals, Birds and Bees). World Organization for Animal Health, Paris, 2015, Chapter 2.3.4, 1- 23.

12. Peiris M.J.S., De Jong D.M., Guan Yi.: Avian influenza virus (H5N1) a threat to human health. Clin Microbiol Rev 2007, 20, (2), 243-267.

13. Perozo F., Villegas P., Estevez C., Alvarado I., Purvis L.B.: Use of FTA filter paper for the molecular detection of Newcastle disease virus. Avian Pathol 2006, 35, 93-98.

14. Scientific Report of EFSA. Higly pathogenic avian influenza A subtype H5N8. EFSA J 2014, 12, 39-41.

15. Spackman E., Senne D.A., Myers T.J., Bulaga L.L., Garber L.P., Perdue M.L.: Development of a real-time reverse transcriptase PCR assay for type A influenza virus and the avian $\mathrm{H} 5$ and $\mathrm{H} 7$ hemagglutinin subtypes. J Clin Microbiol 2002, 40, 3, 256-3260.

16. Starick E., Römer-Oberdörfer A. Werner O.: Type- and subtypespecific RT-PCR assays for avian influenza A viruses (AIV). J Vet Med 2000, 47, 4, 295-301. 